\title{
Computational Design of Thioxanthone Derivatives as Potential Antimalarial Agents through Plasmodium falciparum Protein Inhibition
}

\author{
Faris Hermawan $^{1,2}$, Jumina Jumina ${ }^{1^{*}}$, Harno Dwi Pranowo ${ }^{1,2}$, Eti Nurwening Sholikhah ${ }^{3}$, and Muthia \\ Rahayu Iresha ${ }^{1,2}$
}

${ }^{1}$ Department of Chemistry, Faculty of Mathematics and Natural Sciences, Universitas Gadjah Mada, Sekip Utara, Yogyakarta 55281, Indonesia

${ }^{2}$ Austrian-Indonesian Centre (AIC) for Computational Chemistry, Department of Chemistry, Faculty of Mathematics and Natural Sciences, Universitas Gadjah Mada, Sekip Utara, Yogyakarta 55281, Indonesia

${ }^{3}$ Department of Pharmacology and Therapeutics, Faculty of Medicine, Public Health and Nursing, Universitas Gadjah Mada, Sekip Utara, Yogyakarta 55281, Indonesia

\section{* Corresponding author:}

email: jumina@ugm.ac.id

Received: September 29, 2021

Accepted: November 8, 2021

DOI: $10.22146 /$ ijc. 69448

\begin{abstract}
Plasmodium falciparum (P. falciparum) is the most fatal among the other Plasmodium parasites that infect humans with the malaria disease. Currently, the resistance of $\mathrm{P}$. falciparum against some antifolate drugs has become a severe problem. On the other hand, xanthone and thioxanthone derivatives have been reported to have remarkable antimalarial activity. However, molecular docking studies have not evaluated thioxanthone derivative compounds as antimalarial agents. Accordingly, this research investigated the binding pose and inhibition mechanism of several thioxanthone derivatives against $\mathrm{P}$. falciparum proteins DHFR (PDB ID: 1J3K) and DHODH (PDB ID: 1TV5) through molecular docking study. The compound structures were geometrically optimized using Gaussian 09 software and docked to the receptors using AutoDock4 software. The results showed that the free binding energy of thioxanthone derivatives ranged between -6.77 to -7.50 and -8.45 to $-9.55 \mathrm{kcal} \mathrm{mol}^{-1}$ against pfDHFR and pfDHODH, respectively, with RMSD values of less than 2 A. Compound F (4-iodo-3,4dihydroxy-thioxanthone) gave the most substantial free binding energy against both proteins. Furthermore, the hydrogen bond interaction of compound $F$ was the same as the native ligands of $p f D H F R$ and $p f D H O D H$. These results suggested that compound $F$ has a more robust interaction in $P f D H F R$ and $p f D H O D H$. Thus, it is promising to further evaluate the compound as a candidate for a new antimalarial agent.
\end{abstract}

Keywords: antimalarial; thioxanthone; pfDHFR; pfDHODH; molecular docking

\section{- INTRODUCTION}

Malaria, one of the most acute parasitic diseases globally, is transmitted through the bite of an infected female Anopheles mosquito. According to the World Health Organization (WHO) report in 2020, it was estimated that 229 million new cases and 409,000 deaths from malaria occurred globally. The WHO Regional Office for Africa reported that the region contributed to $94 \%$ of malaria cases and deaths [1]. Six malaria species can infect humans with malaria, i.e., Plasmodium falciparum (P. falciparum), Plasmodium ovale curtisi, Plasmodium vivax, Plasmodium malariae, Plasmodium ovale wallikeri, and Plasmodium knowlesi [2]. Recent epidemiological research shows that $P$. falciparum is the most fatal among the other Plasmodium parasites [3].

Recently, many antimalarial drugs have been examined, such as the antifolates (such as pyrimethamine, proguanil, sulfadoxine, and WR99210), the quinolines (such as chloroquine, quinine, mefloquine, amodiaquine, and primaquine), the artemisinins (such as artemisinin, artesunate, artemether, and arteether)

Faris Hermawan et al. 
and hydroxynaphthaquinones (such as atovaquone) [4], in which the folate antagonist class has become the most used among these antimalarial drugs. Antifolate antimalarial drugs inhibit folate metabolism, an essential pathway for the survival of malaria parasites. Antifolate drugs such as pyrimethamine and cycloguanil inhibit dihydrofolate reductase (DHFR), leading to the inhibition of the biosynthesis of pyrimidines, purines, and several amino acids. Even though antifolate drugs have remarkable antimalarial activity, pyrimethamine and cycloguanil resistance have recently become a problem.

The resistance against DHFR inhibitory antimalarial drugs is generated by the gene mutations encoding dihydrofolate reductase of certain parasites in Plasmodium. Quadruple mutations in the Plasmodium falciparum dihydrofolate reductase (pfDHFR) enzyme cause the high resistance to pyrimethamine cycloguanil but are still sensitive to WR99210 [5], resulting in treatment failures. A mutation of the serine residue at position 108 (Ser108 to Asn108) leads to pyrimethamine resistance and a moderate loss of response to cycloguanil. In contrast, a mutation from Ile164 to Leu164 in combination with Asp108 leads to resistance against pyrimethamine and cycloguanil [6]. In addition to the DHFR protein, the dihydroorotate dehydrogenase $(\mathrm{DHODH})$ protein has also been reported to have an essential role in Plasmodium growth [7]. The DHODH is an enzyme that catalyzes redox reactions that depend on the flavin mononucleotide
(FMN) in the biosynthesis pathway of de novo pyrimidine or the formation of orotic acids. Inhibition of DHODH in the aforementioned pathway causes the death of these cells [8]. However, since many antimalarial drugs encounter resistance in DHFR and DHODH proteins, finding new effective inhibitor agents for both proteins is of high necessity.

There are various strategies to search out and identify new antimalarial drugs. One of the most valuable strategies is to find new antimalarial drugs through a molecular docking study [9-13]. This approach is very effective and efficient in analyzing new drug candidates without any trial and error experiments. Molecular docking analysis can precisely predict the conformation and interaction between two molecules, such as forming a stable complex. The lowest binding energy suggests the most stable complex and is correlated with the strong interactions between ligands and their protein receptors [14].

Due to the high antimalarial activity, and resistance of several drugs to pfDHFR and PfDHODH, these proteins have become an important target in molecular docking studies to develop novel antimalarial drugs [15]. Additionally, those compounds should interact with the amino acid residues of the receptors through Hydrogen-bonding (H-bond) interactions [1617]. Fig. 1 shows the structures of the compounds that meet the aforementioned criteria. Xanthone derivatives<smiles>O=c1c2ccccc2sc2cc(O)ccc12</smiles>

(a)<smiles>O=c1c2ccccc2sc2c(Cl)c(O)cc(O)c12</smiles>

(d)<smiles>O=c1c2ccccc2sc2cc(O)cc(O)c12</smiles>

(b)<smiles>O=c1c2ccccc2sc2c(Br)c(O)cc(O)c12</smiles>

(e)<smiles>O=c1c2ccccc2sc2c(O)c(O)ccc12</smiles>

(c) $\mathrm{OH}$<smiles>Cc1c(O)cc(O)c2c(=O)c3ccccc3sc12</smiles>

(f)

Fig 1. Chemical structures of thioxanthone derivatives involved in this study. (a) 3-hydroxy-thioxanthone, (b) 1,3dihydroxy-thioxanthone, (c) 3,4-dihydroxy-thioxanthone, (d) 4-chloro-3,4-dihydroxy-thioxanthone, (e) 4-bromo3,4-dihydroxy-thioxanthone, (f) 4-iodo-3,4-dihydroxy-thioxanthone 
have been reported to have antimalarial activity [18-20]. Furthermore, hydroxyxanthone as a derivative of xanthone also exhibited effective antimalarial activity [21]. It was also reported that thioxanthone derivatives exhibit good antimalarial activity [22-23]. However, their molecular docking studies have not been evaluated. Accordingly, based on the above considerations, this research aims to investigate the binding pose and inhibition mechanism of several thioxanthone derivatives with hydroxy and halogen substituents (Fig. 1) against DHFR and DHODH proteins of P. falciparum through a molecular docking study.

\section{- EXPERIMENTAL SECTION}

\section{Materials}

The three-dimensional (3D) structures of the proteins of $P$. falciparum were obtained from the Protein Data Bank database (www.rcsb.org) with PDB ID: 1J3K and 1TV5 for pfDHFR and pfDHODH, respectively. The WR99210 ligand (6,6-dimethyl-1-(3-(2,4,5trichlorophenoxy)propoxy)-1,6-dihydro-1,3,5-triazine-2, 4-diamine) was used as a native ligand for pfDHFR protein, while A26 ligand ((2Z)-2-cyano-3-hydroxy-N[4-(trifluoromethyl)phenyl]but-2-enamide) was used as a native ligand for pfDHODH protein. Six thioxanthone derivatives (compounds $\mathbf{A}-\mathbf{F}$ ) were used as the studied ligand models (Fig. 1). The selection of the $\mathbf{A}-\mathbf{F}$ compounds was based on hydroxy groups that allow the formation of $\mathrm{H}$-bonds with amino acid residues.

\section{Procedure}

\section{Preparation of protein molecules}

The preparation of $P$. falciparum (DHFR, DHODH) as a receptor was conducted using Chimera. First, the protein-ligands in the PDB (1J3K and 1TV5) file were cleaned from all of the non-standard residues such as water molecules and native ligands. Then, the hydrogen atoms were added to the protein to make the receptors suitable for docking.

\section{Optimization of thioxanthone derivatives}

Thioxanthone derivatives $\mathbf{A}-\mathbf{F}$ were drawn in $3 \mathrm{D}$ structures using GaussView 5.0, and their structures were optimized with an AM1 method using Gaussian-09
Revision D.01 [24]. The data were saved in the PDB format.

\section{Redocking analysis}

The redocking analysis was conducted using AutoDock 4 in a $50 \times 50 \times 50 \AA$ grid box with a coordinate center $38 \times 35 \times 37 \AA$, and the number of runs Lamarckian Genetic Algorithm (LGA) run was 40. When the RMSD value is less than $2 \AA$, the method is acceptable and can be used further for docking analysis [25-26].

\section{Ligands docking}

The 2D structures of thioxanthone derivatives are shown in Fig. 2. All parameters such as grid map size and LGA were set up the same as the redocking analysis. All compounds were docked in the binding sites of the receptors.

\section{- RESULTS AND DISCUSSION}

\section{Redocking Analysis in Different P. falciparum Proteins}

To determine the accuracy of the docking procedure and to visualize the binding pose of the proteins, the native ligands were docked into their protein receptors. The docking parameters were accurate enough since the root-mean-square deviation (RMSD) values were less than $2 \AA$ [25]. The lowest binding energy of the ligand WRA99210 was $-8.39 \mathrm{kcal} \mathrm{mol}^{-1}$ with the RMSD value of $1.24 \AA$. Meanwhile, the A26 ligand exhibited the binding energy of $-7.56 \mathrm{kcal} \mathrm{mol}^{-1}$ with the RMSD value of $1.69 \AA$. Those results indicated that the docking protocol in our experimental parameters was accurate enough to be used for the docking analysis. The overlapping structures of the native ligands with ligands in the redocking calculation results can be seen in Fig. 2. The position of native ligands (grey color) and the docked conformation (blue color) indicates the similarity with the posts in the docking process. Fig. 3 shows that the H-bonds of WRA99210 ligand with pfDHFR protein took place in Asp54, Ile14, and Leu164 amino acid residues. Meanwhile, the $\mathrm{H}$-bonds of A26 ligands with pfDHODH protein were at Arg265, His185, Cys184, and Met536 amino acid residues. Other studies also reported that docking for the WRA99210 ligands generated Hbonds with Asp54, Ile14, and Leu164 residues [27], while 


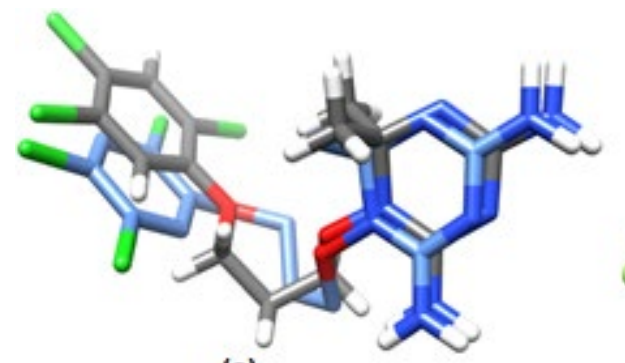

(a)

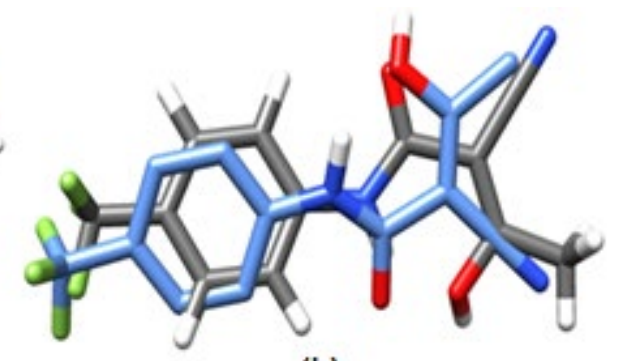

(b)

Fig 2. The overlapping structure of the native ligand of the X-ray crystal structure (grey) to the docking result (blue) and its RMSD values ( $<2 \AA$ ) (a) pfDHFR (b) pfDHODH
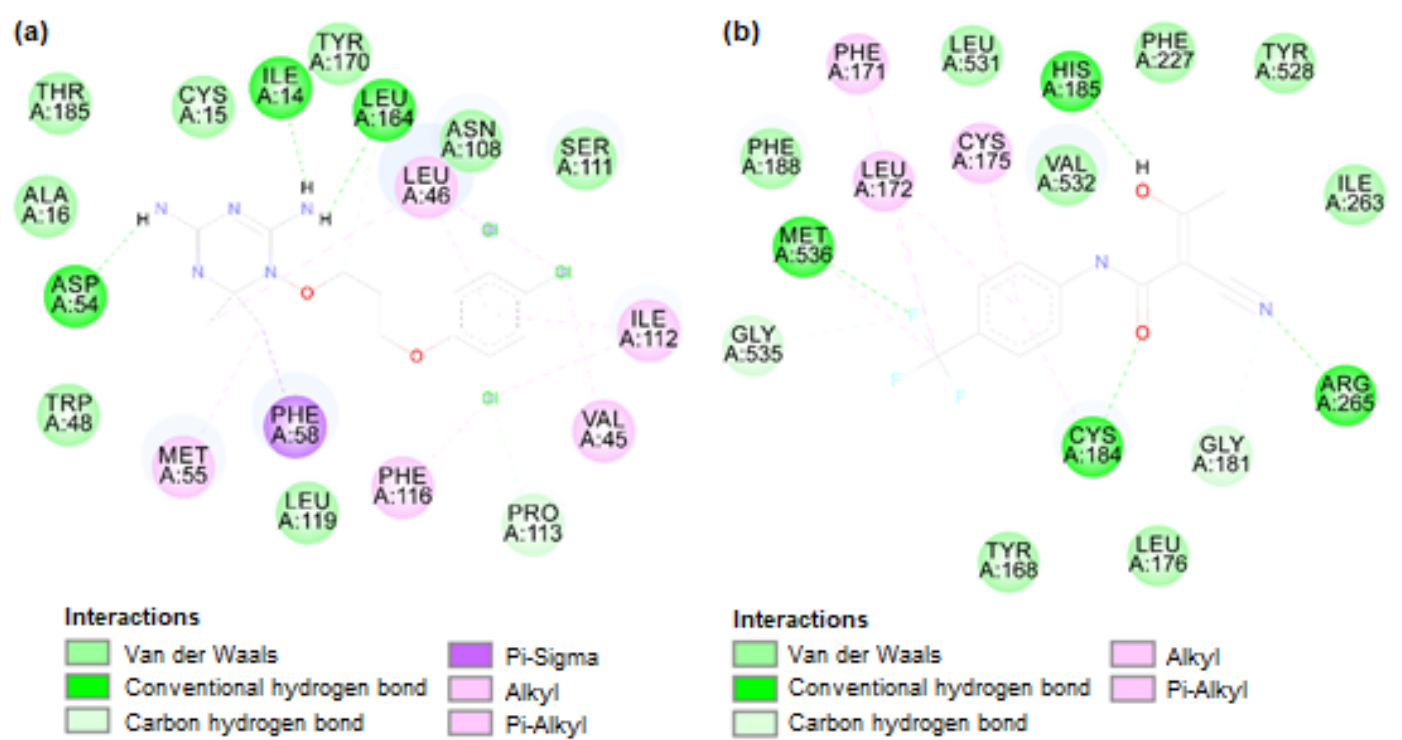

Fig 3. The visualization of hydrogen bondings among docked ligands with amino acid residues of the protein (a) pfDHFR (b) pfDHODH

the A26 ligands received H-bonds at His185, Arg265, and Tyr528 residues [28], which is in agreement with the present study.

\section{Docking Study of Thioxanthone Derivatives Compounds}

Dockings of thioxanthone derivatives (A-F) were studied to calculate the binding energies and investigate their binding pose in the active sites of $P$. falciparum proteins. All compounds were set up to have the same position as the native ligands and docked into $P$. falciparum proteins (pfDHFR and pfDHODH). The first docking study was conducted in the pfDHFR protein. The results showed that compounds $\mathbf{D}, \mathbf{E}$, and $\mathbf{F}$ gave lower binding energy than compounds $\mathbf{A}, \mathbf{B}$, and $\mathbf{C}$. The binding energy of compounds $\mathbf{D}, \mathbf{E}$, and $\mathbf{F}$ were $-7.25,-7.17$, and
$-7.50 \mathrm{kcal} \mathrm{mol}^{-1}$, respectively, with an RMSD range of 0.28-0.56 $\AA$ as displayed in Table 1. From the binding energy data, the addition of either chloro, bromo, or iodo functional groups on the hydroxy-thioxanthone decreased the binding energy value. This result demonstrates that halogen substituents $(\mathrm{Cl}, \mathrm{Br}, \mathrm{I})$ have higher biological activity as a pfDHFR inhibitor compared to just hydroxy-substituents on thioxanthones. All compounds had the same H-bond interactions in the amino acid residues of Asp54, with WRA99210 as the native ligand. The results suggested that all compounds possessed the exact inhibition mechanism with Ligand WRA99210 as the native ligand.

The H-bond of compounds $\mathbf{C}$ and $\mathbf{D}$ took place in the amino acid residues of Asn108. In contrast, compound $\mathbf{B}$ had $\mathrm{H}$-bond in the amino acid residues of 
Table 1. The docking results of compounds A-F and WRA99210 with pfDHFR receptor

\begin{tabular}{lclc}
\hline Compound & $\begin{array}{c}\text { Binding Energy } \\
\left(\mathrm{kcal} \mathrm{mol}^{-1}\right)\end{array}$ & $\begin{array}{l}\text { Hydrogen } \\
\text { Bond }\end{array}$ & $\begin{array}{c}\text { RMSD } \\
(\AA)\end{array}$ \\
\hline \multirow{2}{*}{ Ligand WRA99210 } & -8.39 & $\begin{array}{l}\text { Ile14 } \\
\text { Asp54 }\end{array}$ & 1.24 \\
& & $\begin{array}{l}\text { Leu164 } \\
\text { Ala16 }\end{array}$ & 0.39 \\
A & -6.77 & $\begin{array}{l}\text { Asp54 } \\
\text { Asn108 }\end{array}$ & 0.54 \\
B & -6.95 & Asp54 & \\
& & Leu164 & \\
C & & Asn108 & 0.37 \\
& -7.05 & Asp54 & \\
D & & Asn108 & 0.46 \\
& -7.25 & Ala16 & \\
& & Asp54 & \\
E & & Ala16 & 0.51 \\
& -7.17 & Asp54 & \\
& & Tyr170 & \\
F & & Ala16 & 1.51 \\
& -7.50 & Asp54 & \\
& & Tyr170 & \\
\hline
\end{tabular}

Leu164 and Asn108. The compounds A, E, and F formed van der Waals interaction in the amino acid residues of Leu164 and Asn108. The H-bond interaction at position 108 (Asn108) and Leu164 indicate that the compound could develop resistance in the pfDHFR mutants [26]. The results showed that all compounds had a probability of developing resistance against PfDHFR mutants.

Additionally, the interactions of those compounds were not just $\mathrm{H}$-bonds and van der Waals but also involved $\pi$-alkyl interaction and $\pi-\pi$ stacking interactions. These interactions suggested that the interactions between ligands and receptors were positively affected by the existence of the thioxanthone ring, as shown in Fig. 4. Compounds with strong interactions have the lowest binding energy [29]; thus, compound $\mathbf{F}$ with iodosubstituents was identified as the best ligand exhibiting good inhibition activity and had a high probability of developing resistances against PfDHFR mutants.

(b)
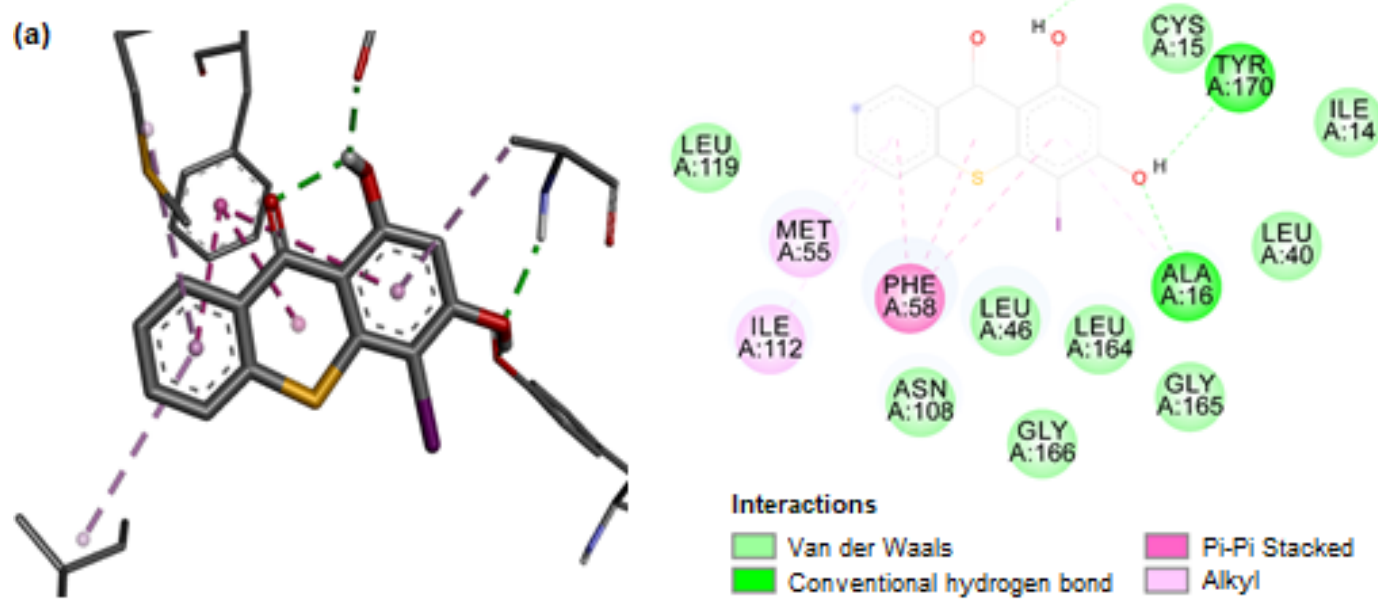

Fig 4. The binding affinities of compound $\mathbf{F}$ with pfDHFR protein in (a) $3 \mathrm{D}$ and (b) $2 \mathrm{D}$ visualization 
The docking study of thioxanthone derivatives in pfDHODH protein showed that all compounds had lower binding energy than A26 as a native ligand. The binding energy of all compounds was in the range of -8.45 to -9.55 $\mathrm{kcal} \mathrm{mol}^{-1}$, with the RMSD range of 0.28-0.56 $\AA$ (Table 2): the lower the binding energy value, the more stable the protein-ligand complex [30]. The binding energy of all compounds was also lower than benzamide derivatives, with binding energy in the range of -2.84 to $-4.11 \mathrm{kcal}$ $\mathrm{mol}^{-1}[11]$. This means that the stability of the complex between thioxanthone derivatives compounds (A-F) with pfDHODH protein was higher than that of ligand A26, implying that its effectiveness as an antimalarial drug is theoretically effective also better than A26 as a native ligand. The addition of either chloro, bromo, or iodo functional group on hydroxy-thioxanthone decreased the binding energy value from the binding energy data. This result demonstrates that halogen substituent $(\mathrm{Cl}, \mathrm{Br}, \mathrm{I})$ has a higher biological activity as pfDHODH inhibitor than just hydroxy-substituent on thioxanthones.

Compounds D, E, and F had the H-bond interactions in the amino acid residues of Arg265, Gly18, and Val532 (Fig. 5), similar to the A26 ligands as native ligand. The Key H-bond interactions between the pfDHODH with inhibitor were His185 and Arg265 residues [31]. These $\mathrm{H}$-bond interactions indicate that compounds $\mathbf{D}, \mathbf{E}$, and $\mathbf{F}$ are predicted to have the same inhibitory activity against PfDHODH protein as the A26 ligand. The interaction of those compounds was not just through H-bonds, but also through van der Waals, $\pi-\pi$ stacking, $\pi$-lone pair, and $\pi$-sulfur interactions. It was found that compound $\mathbf{F}$ exhibits the lowest binding energy value. Thus, it can potentially be evaluated for its in vitro and in vivo antimalarial activities.

Table 2. Docking results of all compounds with pfDHODH protein

\begin{tabular}{lccc}
\hline Compound & $\begin{array}{c}\text { Binding Energy } \\
\left(\mathrm{kcal} \mathrm{mol}^{-1}\right)\end{array}$ & $\begin{array}{c}\text { Hydrogen } \\
\text { Bond }\end{array}$ & $\begin{array}{c}\text { RMSD } \\
(\AA)\end{array}$ \\
\hline & & $\begin{array}{c}\text { His185 } \\
\text { Arg265 } \\
\text { Cys184 }\end{array}$ & 1.69 \\
& -7.56 & Met536 & \\
A & & Gly181 & 0.28 \\
B & -8.45 & Arg265 & 0.41 \\
& -8.51 & His185 & \\
C & & His185 & 0.39 \\
D & -8.23 & Arg265 & 0.28 \\
& -9.06 & Gly181 & \\
& & Val532 & \\
E & & Arg265 & 0.49 \\
& -9.02 & Gly181 & \\
F & & Val532 & \\
& & Arg265 & 0.64 \\
& -9.55 & Gly181 & \\
\hline
\end{tabular}

(b)
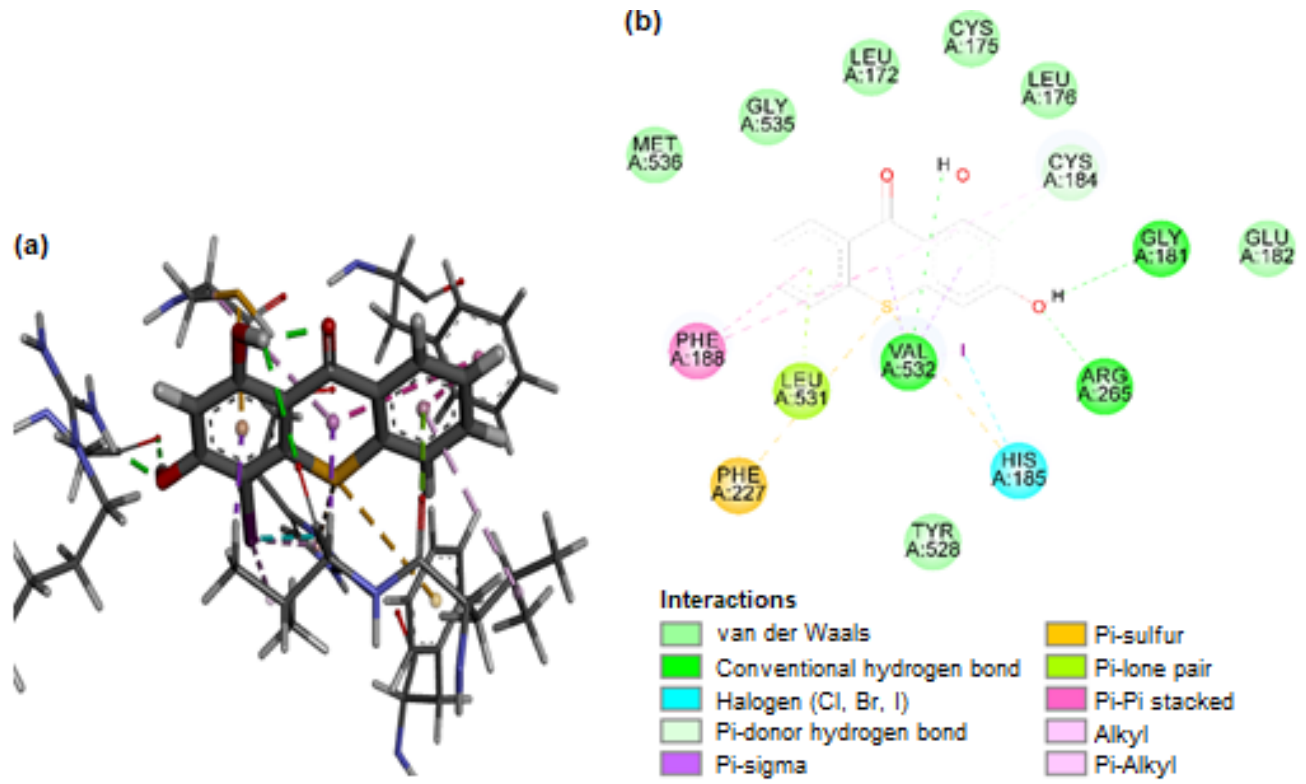

Fig 5. The binding affinities of compound $\mathbf{F}$ with pfDHODH protein in (a) $3 \mathrm{D}$ and (b) $2 \mathrm{D}$ visualization 


\section{Comparison of Docking Study Results of pfDHFR and pfDHODH}

A docking study of pfDHFR protein showed that the binding energies of thioxanthone derivatives were higher than that of the WRA99210 as a native ligand. In contrast, the docking study of the $\mathrm{pfDHODH}$ protein showed that the binding energies of thioxanthone derivatives were lower than that of the A26 ligand, which is remarkable. Furthermore, the docking results suggested that thioxanthone derivatives had better inhibitory activity against the $\mathrm{pfDHODH}$ protein than the pfDHFR protein. Thus, thioxanthone derivatives are potential candidates for the invention of novel antimalarial drugs.

\section{- CONCLUSION}

Since $P$. falciparum proteins, i.e., DHFR and $\mathrm{DHODH}$, are essential as drug-targeted proteins for curing malaria, all thioxanthone derivatives have been studied using molecular docking simulations on those proteins to find antimalarial drug candidates. From the comparison of pfDHFR and pfDHODH docking studies, it was found that thioxanthone derivatives gave higher binding energy to pfDHFR than the WRA99210 ligand. In contrast, thioxanthone derivatives gave lower binding energy towards the pfDHODH protein compared to the A26 ligand. Among the six thioxanthone derivatives, compound $\mathbf{F}$ gave the lowest binding energy in both pfDHFR and pfDHODH proteins, which is remarkable. The H-bonds of compound $\mathbf{F}$ occurred in amino acid residues of Ala16, Asp54, and Tyr170 for the pfDHFR protein, and in amino acid residues of Arg265, Gly18, Val532 for the pfDHOD protein. Thus, compound $\mathbf{F}$ is a potential candidate to be used in the invention of novel antimalarial drugs.

\section{- ACKNOWLEDGMENTS}

The authors sincerely thank KEMRISTEKDIKTI for the financial support of this research and for the Pendidikan Magister Menuju Doktor Untuk Sarjana Unggul (PMDSU) scholarship awarded to Faris Hermawan. Special gratitudes are also expressed for the Gaussian 09 licenses provided by the AustrianIndonesian Centre (AIC) for Computational Chemistry.

\section{REFERENCES}

[1] World Health Organization, 2020, World Malaria Report 2020, World Health Organization, Geneva, Switzerland.

[2] Lalremruata, A., Jeyaraj, S., Engleitner, T., Joanny, F., Lang, A., Bélard, S., Mombo-Ngoma, G., Ramharter, M., Kremsner, P.G., Mordmuller, B., and Held, J., 2017, Species and genotype diversity of Plasmodium in malaria patients from Gabon analysed by next generation sequencing, Malar. J., $16,398$.

[3] Blasco, B., Leroy, D., and Fidock, D.A., 2017, Antimalarial drug resistance: Linking Plasmodium falciparum parasite biology to the clinic, Nat. Med., 23 (8), 917-928.

[4] Saifi, M.A., Beg, T., Harrath, A.H., Altayalan, F.S.H., and Al Quraishy, S., 2013, Antimalarial drugs: Mode of action and status of resistance, Afr. J. Pharm. Pharmacol., 7 (5), 148-156.

[5] Yuvaniyama, J., Chitnumsub, P., Kamchonwongpaisan, S., Vanichtanankul, J., Sirawaraporn, S., Taylor, P., Walkinshaw, M.D., and Yuthavong, Y., 2003, Insights into antifolate resistance from malarial DHFR-TS structures, Nat. Struct. Mol. Biol., 10, 357-365.

[6] Mishra, R., Mishra, B., and Hari, N.S.H.N., 2006, Dihydrofolate reductase enzym: A potent target for antimalarial research, Asian J. Cell Biol., 1 (1), 4558.

[7] Phillips, M.A., and Rathod, P.K., 2010, Plasmodium dihydroorotate dehydrogenase: A promising target for novel antimalarial chemotherapy, Infect. Disord.: Drug Targets, 10 (3), 226-239.

[8] Vyas, V.K., and Ghate, M., 2011, Recent developments in the medicinal chemistry and therapeutic potential of dihydroorotate dehydrogenase (DHODH) inhibitors, Mini-Rev. Med. Chem., 11 (12), 1039-1055.

[9] Syahri, J., Yuanita, E., Nurohmah, B.A., Wathon, M.H., Syafri, R., Armunanto, R., and Purwono, B., 2017, Xanthone as antimalarial: QSAR analysis, synthesis, molecular docking and in-vitro 
antimalarial evaluation, Orient. J. Chem., 33 (1), 2940.

[10] Wadood, A., and Ul-Haq, Z., 2013, In silico identification of novel inhibitors against Plasmodium falciparum dihydroorate dehydrogenase, J. Mol. Graphics Modell., 40, 40-47.

[11] Singh, I.V., and Mishra, S., 2019, Molecular docking studies of benzamide derivatives for PfDHODH inhibitor as potent antimalarial agent, Am. J. Biochem. Mol. Biol., 9 (1), 1-6.

[12] Syahri, J., Yuanita, E., Nurohmah, B.A., Armunanto, R., and Purwono, B., 2017, Chalcone analogue as potent antimalarial compounds against Plasmodium falciparum: Synthesis, biological evaluation, and docking simulation study, Asian Pac. J. Trop. Biomed., 7 (8), 675-679.

[13] Brandão, G.C., Missias, F.C.R., Arantes, L.M., Soares, L.F., Roy, K.K., Doerksen, R.J., de Oliveira, A.B., and Pereira, G.R., 2018, Antimalarial naphthoquinones. Synthesis via click chemistry, in vitro activity, docking to PfDHODH and SAR of lapachol-based compounds, Eur. J. Med. Chem., 145, 191-205.

[14] Mukesh, B., and Rakesh, K., 2011, Molecular docking: A review, Int. J. Res. Ayurveda Pharm., 2 (6), 1746-1751.

[15] Ojo, A.A., 2021, Exploring the potential of selected bioactive compound isolated from Piper guineense Schumach. \& Thonn. Leaf toward identification of novel pfDHFR and pfDHODH inhibitors as antimalaria agents, J. Appl. Pharm. Sci., 11 (4), 153158.

[16] Adane, L., Bhagat, S., Arfeen, M., Bhatia, S., Sirawaraporn, R., Sirawaraporn, W., Chakraborti, A.K., and Bharatam, P.V., 2014, Design and synthesis of guanylthiourea derivatives as potential inhibitors of Plasmodium falciparum dihydrofolate reductase enzyme, Bioorg. Med. Chem. Lett., 24 (2), 613-617.

[17] Vyas, V.K., Qureshi, G., Ghate, M., Patel, H., and Dalai, S., 2016, Identification of novel PfDHODH inhibitors as antimalarial agents via pharmacophorebased virtual screening followed by molecular docking and in vivo antimalarial activity, SAR QSAR Environ. Res., 27 (6), 427-440.
[18] Amanatie, A., Jumina, J., Mustofa, M., Hanafi, M., Kadidae, L.A., and Sahidin, I., 2017, Synthesis of 2hidroxyxanthone from xanthone as a basic material for new antimalarial drugs, Asian J. Pharm. Clin. Res., 10 (12), 242-246.

[19] Lyles, J.T., Negrin, A., Khan, S.I., He, K., and Kennelly, E., 2014, In vitro antiplasmodial activity of benzophenones and xanthones from edible fruits of Garcinia species, J Planta Med., 80 (9), 676-681.

[20] Upegui, Y., Robledo, S.M., Gil Romero, J.F., Quinones, W., Archbold, R., Torres, F., Escobar, G., Nariño, B., and Echeverri, F., 2015, In vivo antimalarial activity of $\alpha$-mangostin and the new xanthone $\delta$-mangostin, Phytother. Res., 29 (8), 1195-1201.

[21] Auranwiwat, C., Limtharakul T., Pyne, S.G., Rattanajak, R., and Kamchonwongpaisan, S., 2021, A new xanthone and a biphenyl from the flower and twig extract of Garcinia mckeaniana, Nat. Prod. Res., 35 (20), 3404-3409.

[22] Charris, J., Dominguez, J., Lobo, G., and Riggione, F., 1999, Synthesis of some thiochromone derivatives and activity against Plasmodium falciparum in-vitro, Pharm. Pharmacol. Commun., 5 (2), 107-110.

[23] Hung, J., McNamara, D.J., and Werbel, L.M., 1983, Synthesis of 3,4-dihydrothioxanthene-1,9-dione analogs as potential antimalarial agents, $J$. Heterocycl. Chem., 20 (6), 1575-1580.

[24] Frisch, M.J., Trucks, G.W., Schlegel, H.B., Scuseria, G.E., Robb, M.A., Cheeseman, J.R., Scalmani, G., Barone, V., Mennucci, B., Petersson, G.A., Nakatsuji, H., Caricato, M., Li, X., Hratchian, H.P., Izmaylov, A.F., Bloino, J., Zheng, G., Sonnenberg, J.L., Hada, M., Ehara, M., Toyota, K., Fukuda, R., Hasegawa, J., Ishida, M., Nakajima, T., Honda, Y., Kitao, O., Nakai, H., Vreven, T., Montgomery, J.A., Jr., Peralta, J.E., Ogliaro, F., Bearpark, M., Heyd, J.J., Brothers, E., Kudin, K.N., Staroverov, V.N., Kobayashi, R., Normand, J., Raghavachari, K., Rendell, A., Burant, J.C., Iyengar, S.S., Tomasi, J., Cossi, M., Rega, N., Millam, J.M., Klene, M., Knox, J. E., Cross, J.B., Bakken, V., Adamo, C., Jaramillo, 
J., Gomperts, R., Stratmann, R.E., Yazyev, O., Austin, A.J., Cammi, R., Pomelli, C., Ochterski, J.W., Martin, R.L., Morokuma, K., Zakrzewski, V.G., Voth, G. A., Salvador, P., Dannenberg, J. J., Dapprich, S., Daniels, A. D., Farkas, Ö., Foresman, J. B., Ortiz, J.V., Cioslowski, J., and Fox, D.J., 2013, Gaussian-09 Revision D.01, Gaussian, Inc., Wallingford, CT.

[25] Ramirez, D., and Cabello, J., 2018, Is it reliable the molecular docking top scoring position as the best solution without considering available structural data?, Molecules, 23 (5), 1038-1055.

[26] Yogaswara, R., Pulung M.L., Yuliani, S.H., and Istiyanto, E.P., 2020, Docking-guided 3D-QSAR studies of 4-aminoquinoline-1,3,5-triazines as inhibitors for Plasmodium falciparum dihdrofolate reductase, Indones. J. Chem., 20 (6), 1455-1460.

[27] Siswanto, I., Pranowo, H.D., and Mudasir, M., 2019, Docking of new designed compounds derived from 1,6-dihydro-1,3,5-triazine-2,4-diamine toward quadruple mutant plasmodium dihydrofolate reductase, Indones. J. Chem., 19 (3), 777-785.

[28] Scolastica, M., Ndakala, A.J., and Derese, S., 2108, Modeling and synthesis of antiplasmodial chromones, chromanones, and chalcone based on natural product of Kenya, Asian J. Nat. Prod. Biochem., 16 (1), 8-21.

[29] Singh, I.V., and Mishra, S., 2018, Molecular docking analysis of pyrimethamine derivatives with Plasmodium falciparum dihydrofolate reductase, Bioinformation, 14 (5), 232-235.

[30] Murthy, S.S., and Narsaiah, T.B., 2019, Molecular docking studies of phytocompounds with transcriptional factors in hepatocellular carcacinoma, Rasayan J. Chem., 12 (4), 2030-2038.

[31] Pavadai, E., Mazouni, F.E., Wittlin, S., de Kock, C., Phillips, M.A., and Chibale, K., 2016, Identification of new human malaria parasite Plasmodium falciparum dihroorotate dehydrogenase inhibitors by pharmacophore and structure-based virtual screening, J. Chem. Inf. Model., 56 (3), 548-562. 